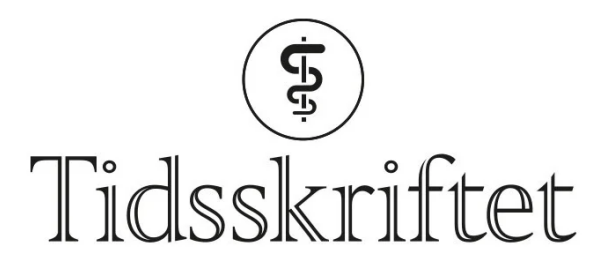

DEN NORSKE LEGEFORENING

\title{
Hjerneslagpasienter kommer for sent til behandling
}

NYHETER

KASHIF WAQAR FAIZ

Email: kashif.faiz@medisin.uio.no

Nevroklinikken

Akershus universitetssykehus

og

Institutt for klinisk medisin

Universitetet i Oslo

\section{Altfor mange pasienter med akutt hjerneslag kommer for sent til sykehus og intravenøs trombolytisk behandling.}

Ved et stort hjerneinfarkt forsvinner 1,7 millioner nevroner per minutt. Derfor er det viktig at intravenøs trombolytisk behandling påbegynnes så raskt som mulig. Dessverre får kun en liten andel av pasientene slik behandling raskt nok. Prehospital forsinkelse, dvs.

forsinket ankomst til akuttmottaket, er den viktigste årsaken til at så få får trombolytisk behandling.

Vi har gjennomført en prospektiv studie hvor 440 pasienter med hjerneinfarkt, intracerebral blødning og TIA ble inkludert (1). Tid fra symptomdebut til ankomst til akuttmottaket ble registrert og faktorer relatert til prehospital forsinkelse analysert.

Median tid fra symptomdebut til innleggelse var tre timer, hvorav omtrent halvparten var tiden fra symptomdebut til første medisinske kontakt (AMK-sentral, legevakt, fastlege eller direkte oppmøte i akuttmottak). Rundt $12 \%$ av pasientene ankom akuttmottaket etter 24 timer.

Multivariat lineær regresjonsanalyse viste at uttalte symptomer/utfall, bruk av ambulanse og lav alder var relatert til rask innleggelse. Det var ingen signifikant sammenheng mellom prehospital forsinkelse og kjønn, utdanningsnivå, tidligere cerebrovaskulær hendelse, tidligere hjertesykdom eller typiske risikofaktorer for hjerte- og karsykdom.

Resultatene kan tyde på at folk har lite kunnskap om hjerneslag og om nødvendigheten av rask behandling. At pasienter som tidligere hadde vært innlagt med hjerneslag eller TIA ikke kommer tidligere enn andre, kan tyde på at helsepersonell ikke informerer godt nok om risikofaktorer og symptomer ved hjerneslag og at tid er av avgjørende betydning for 
utfallet. Pasienter med mistenkt hjerneslag bør ringe 113 så raskt som mulig og bringes direkte til sykehus. Kunnskap om hjerneslag og hjerneslagbehandling hos helsepersonell og i befolkningen bør bedres.

\section{LITTERATUR}

1. Faiz KW, Sundseth A, Thommessen B et al. Prehospital delay in acute stroke and TIA. Emerg Med J 2012. E-publisert 14.8. [PubMed] [CrossRef]

Publisert: 12. november 2012. Tidsskr Nor Legeforen. DOI: 10.4045/tidsskr.12.1141

(C) Tidsskrift for Den norske legeforening 2023. Lastet ned fra tidsskriftet.no 26. april 2023. 